Vol. V No. 2, Maret 2021, hlm. 145 - 150

DOI: https://doi.org/10.36294/jmp.vxix.xxx

Available online www.jurnal.una.ac.id/indeks/jmp

\title{
PROGRAM PENENTUAN POHON RENTANG MINIMUM PADA APLIKASI MICROSOFT VISUAL BASIC 6.0.
}

\author{
Nina Zakiah \\ Prodi Ekonomi Syaria'h, Sekolah Tinggi Agama Islam Negeri (STAIN) Bengkalis \\ email: ok_zakiahms@yahoo.com
}

\begin{abstract}
Minimum spanning tree has been used to solve several problem, such as cost saving in electrical installation. Electrical instalation design is described in weighted graph form. the weighted graph value is a cable length. to find a minimum spanning tree in this research, the Kruskal algorithm is used. Kruskal algorithm Procedure will be describe in a flow chart. then according to the flowchart, a program designed with visual basic 6.0. this research will produce a program to solve minimum spanning tree with the Kruskal algorithm on visual basic 6.0 application support. test the program to solve one of problems. This application is divided many form such as menu form, description form, input form, and matrix and tree form.
\end{abstract}

Keywords: Minimum Spanning Tree, Visual Basic.

\begin{abstract}
Abstrak
Pohon rentang minimum ini aplikasinya dapat direpresentasikan matriks bobot sebagai bentuk perkembangan dari matriks hubung. Menentukan pohon rentang minimum pada jurnal ini menggunakan algoritma kruskal dan diimplementasikan dalam bentuk pemrograman. Dalam tulisan ini digunakan bahasa pemrograman Visual basic Basic 6.0. Jurnal ini merupakan mengkaji teori-teori mengenai masalah Penentuan Pohon rentang minimum. Dengan pendekatan masalah yaitu : teori graf, pohon, penentuan pohon rentang minimum, algoritma Kruskal serta Microsoft Visual Basic 6.0. Selanjutnya di implementasikan pada program penentuan pohon rentang minimum.
\end{abstract}

Kata Kunci: Pohon Rentang Minimum, Visual Basic 6.0 


\section{MATEMATICS PAEDAGOGIC}

Vol. V No. 2, Maret 2021, hlm. 145 - 150

DOI: https://doi.org/10.36294/jmp.vxix.xxx

Available online www.jurnal.una.ac.id/indeks/jmp

\section{PENDAHULUAN}

Salah satu cara efisiensi biaya dalam pemasangan listrik adalah pengoptimalan penggunaan kabel listrik, artinya panjang kabel yang digunakan seminimal mungkin namun tidak mengurangi efektifitas fungsinya untuk menyampaikan arus listrik. Metode yang dapat digunakan dalam meminimumkan panjang kabel listrik adalah pohon rentang minimum. Caranya terlebih dahulu jaringan listrik yang akan dipasang direpresentasikan dalam bentuk graf terhubung tak berarah dan berbobot, dari graf tersebut dibentuk beberapa pohon rentang, lalu pilih pohon rentang yang memiliki bobot paling kecil (pohon rentang minimum).

Cara lain menentukan pohon rentang minimum dapat menggunakan beberapa algoritma, seperti algoritma prim yang ditemukan oleh Robert C. Prim dan algoritma kruskal yang dirancang oleh Joseph Kruskal. Algoritma Prim berorientasi langsung pada pencarian sisi- sisi yang berbobot minimum berdasarkan simpul yang diambil, jadi tidak perlu mengurutkan sisi - sisi pada graf sesuai dengan bobotnya. Algoritma Kruskal menitik beratkan pemilihan sisi berdasarkan urutan bobotnya. Pengurutan sisi - sisi pada graf berdasarkan bobotnya sangat diperlukan pada penyelesaian masalah yang menggunakan algoritma Kruskal. Sisi yang dipilih pada agoritma ini tidak boleh membentuk sikel namun tidak perlu bersisian pada simpul di T.

Pencarian pohon rentang minimum pada Graf yang mengandung simpul lebih banyak dari pada sisi atau graf yang mengandung beberapa pohon lebih efisien meggunakan Algoritma kruskal.

Algoritma kruskal dapat di terapkan secara manual dengan mengikuti tahap demi tahap sesuai prosedurnya. Pada graf yang besar (graf yang memiliki simpul dan sisi banyak) penerapan algoritma ini secara manual masih tergolong sulit dan memerlukan waktu yang lama. Kemampuan manusia untuk berkonsentrasi dalam penyelesaian algoritma kruskal tahap demi tahap tidaklah selalu baik, sehingga sering terjadi kesalahan.

Sejalan dengan perkembangan teknologi informasi, semakin bertambah pula kemampuan komputer dalam membantu penyelesaian permasalahan di berbagai bidang. Aplikasi pemrograman dapat dirancang sedemikian rupa untuk memudahkan penyelesaian masalah. Tulisan ini membahas perancangan program yang dapat memudahkan penggunaan algoritma kruskal dalam menentukan pohon rentang minimum dengan bantuan aplikasi Komputer.

Aplikasi Komputer yang digunakan pada tulisan ini adalah Microsoft visual basic 6.0 yaitu salah satu development tools yang membangun aplikasi dalam lingkungan Windows (under windows) dan berorientasi langsung pada objek (oriented objected). Aplikasi ini menggunakan pendekatan visual untuk merancang user interface dalam bentuk form. Berdasarkan latar belakang, pembahasan pada tulisan ini adalah “ Program penentuan pohon rentang 


\section{MATEMATICS PAEDAGOGIC}

Vol. V No. 2, Maret 2021, hlm. 145 - 150

DOI: https://doi.org/10.36294/jmp.vxix.xxx

Available online www.jurnal.una.ac.id/indeks/jmp

minimum dengan algoritma kruskal menggunakan aplikasi visual basic 6.0"

\section{METODE}

Penelitian ini merupakan penelitian dasar (teoritis). Metode yang digunakan adalah metode deskriptif yang didasarkan pada studi literatur dan hasil analisis beberapa teori yang relevan dengan permasalahan yang dibahas.

Metode penelitian yang digunakan pada tulisan ini adalah metode deskrifti yaitu mengkaji masalah-masalah yang relevan atau berkaitan dengan pohon rentang minimum dan kemudian mengumpulkan beberapa teori yang mendukung penelitian ini seperti teori graph, pohon rentang minimum, algoritma Kruskal dan teori dasar tentang Microsoft Visual Basic 6.0, selanjutnya menghubungkan beberapa teori. Jika relevan sudah ditemukan masalah yang dibahas, kemudian dilanjutkan dengan perancangan program studi ini pada aplikasi visual Basic 6.0 untuk memudahkan penentuan algoritma spanning tree minimum menggunakan Kruskal. dan yang terakhir adalah menguji program yang telah dirancang sesuai dengan permasalahan yang ada.

\section{HASIL DAN PEMBAHASAN}

A. Perancangan Program

Perancangan program aplikasi visual basic biasanya diawali dengan mengaktifkan visual basic IDE (integrated developement enviranment) dan memilih jenis proyek yang dibutuhkan dalam pembuatan program.
Dalam proyek penelitian telah dibuat proyek standar .exe yang berisi menu standar untuk digunakan dalam pembuatan program. Dalam penelitian ini penambahan form dibutuhkan lebih dari satu untuk merancang tampilan antarmuka yang lebih menarik bagi pengguna. Beberapa bentuk yang digunakan dalam penelitian ini sebagai berikut.

1. Menu Form

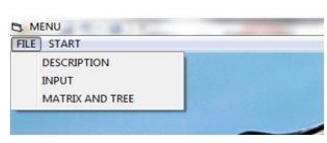

Gambar . 1. Menu form

Form ini digunakan sebagai form tampilan yang pertama kali muncul pada saat program dijalankan, dengan tujuan form menu ini dapat menampilkan beberapa form selanjutnya yang terdapat pada program. Di bagian atas formulir ini diberikan dua opsi utama yang akan menjadi pilihan pengguna. Pilihan pertama dengan menulis file memiliki tujuan utama ketika pengguna mengarahkan kursor ke file akan muncul beberapa nama form yang akan muncul seperti deskripsi, input, matriks \& pohon. Jika pengguna mengklik kursor pada nama formulir, maka pengguna melihat formulir yang sesuai dengan nama formulir. Selanjutnya opsi kedua yang bertuliskan Start memiliki tujuan utama ketika pengguna memilih opsi ini, program akan menampilkan form deskripsi.

\section{Form Input}

Formulir ini dirancang untuk mendeskripsikan nama program sebelum pengguna mulai memasukkan data. Form ini dilengkapi dengan 


\section{MATEMATICS PAEDAGOGIC}

Vol. V No. 2, Maret 2021, hlm. 145 - 150

DOI: https://doi.org/10.36294/jmp.vxix.Xxx

Available online www.jurnal.una.ac.id/indeks/jmp

tombol Next sehingga pada saat user memilih tombol maka aplikasi akan menampilkan form selanjutnya yaitu Input

\section{Form input}

Formulir ini dirancang sedemikian rupa untuk menginput jumlah simpul dan sisi (penghubung antara simpul dengan simpul lain) dan menimbang kedua sisi yang menghubungkan simpul tersebut. Pada form ini juga diberi frame bernama Connection Edges, pada frame tersebut diberi beberapa label yaitu:

1) Label2 diberikan dengan tulisan Initial Vertex yang berarti kotak putih yang terletak tepat di samping label 2 sebagai nama node awal pengguna.

2) Label3 diberikan dengan tulisan End Vertex, artinya kotak putih yang terletak tepat di samping pengguna Label3 dapat digunakan sebagai tempat untuk menuliskan nama node tujuan.

3) Label4 diberikan dengan tulisan Edge yang artinya kotak putih yang terletak tepat di sebelah Label4 dimana pengguna menuliskan jumlah edge yang menghubungkan node cloud dan node tujuan.

4) Label5 diberikan dengan menuliskan bobot, artinya kotak putih yang terletak tepat di samping Label5 adalah tempat pengguna menuliskan nilai bobot sisi yang menghubungkan node cloud dengan node tujuan.

Pada frame ini diberikan 4 Command Button yang memiliki fungsi berbeda yaitu:

\section{1) Simpan}

Command Button ini dirancang untuk menyimpan data yang telah dimasukkan ke dalam database. Dalam program ini database menggunakan Microsoft Access sebagai basis datanya.

2) Hapus

Tombol ommand ini dirancang untuk menghapus data yang telah dimasukkan

3) Proses

Command Button ini dirancang untuk melakukan proses pembentukan pohon rentang minimum sesuai algoritma Kruskal grafik yang telah dimasukkan, selain itu Tombol Perintah juga menampilkan jumlah dan bobot total pohon rentang minimum yang dihasilkan.

4) Matriks

Command Button dirancang untuk menampilkan matriks pohon rentang minimum melalui kotak teks yang terletak dalam bentuk matriks dan pohon.

Formulir ini juga diletakkan di DataGrid yang terkait dengan Adodc1. Adodc1 dirancang untuk menghubungkan DataGrid dengan basis data sehingga DataGrid dapat menampilkan data yang telah dimasukkan ke dalam basis data.

\section{Matriks dan Pohon}

Formulir ini ditempatkan pada kotak sebagai kotak teks untuk menampilkan matriks pohon rentang minimum, dan Command Botton dengan pohon katakata yang dirancang untuk menampilkan gambar dari pohon rentang minimum dalam kotak gambar yang terletak di bawah kotak teks.

\section{B. Uji program}

Dalam penelitian ini dilakukan pengujian program untuk menye- 


\section{MATEMATICS PAEDAGOGIC}

Vol. V No. 2, Maret 2021, hlm. 145 - 150

DOI: https://doi.org/10.36294/jmp.vxix.Xxx

Available online www.jurnal.una.ac.id/indeks/jmp

lesaikan permasalahan pemasangan kabel listrik yang optimal pada desain rumah yang akan dibangun. Rencananya, ruangan-ruangan pada rumah yang akan dibangun diberi penerangan secara paralel, pada rumah tersebut juga akan dilengkapi dengan sekring dan pengatur listrik mbc yang masing-masing ruangan dalam rumah tersebut.

pada besain rumah diberi tanda membutuhkan listrik. Pada gambar tersebut diberi tanda menjadi node dalam suatu grafik, kemudian node tersebut dapat ditarik dari samping sebagai simbol kemungkinan kabel untuk dipasang. Di rumah ada enam ruangan yang membutuhkan listrik.

Mengoptimalkan penggunaan kabel listrik pada desain rumah di atas dapat dilakukan dengan membuat pohon rentang minimum. sebelum pembentukan minimum spanning tree desain listrik direncanakan untuk rumah pertama yang digambarkan dalam bentuk grafik. Adapun gambar grafik desain kelistrikan rumah dapat dilihat pada Gambar 2

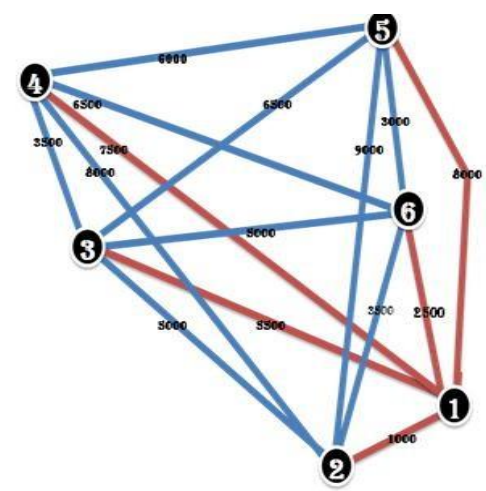

Gambar 2. Grafik Desain Kelistrikan Rumah
Pada gambar 2 terlihat lambang suatu titik dengan angka. Pada titik bantalan angka 1 merupakan letak sekring, maka setiap sisi dari titik penghubung yang bertuliskan angka 1 ke titik lainnya diberi tanda berwarna merah. Sedangkan titik yang tidak lain berlambang angka 1 adalah suatu tempat yang mem-butuhkan arus listrik. Titik sambung samping yang tidak berhubungan langsung dengan titik bantalan nomor 1 ditandai dengan warna biru.

Hasil pencarian grafik pohon rentang minimum adalah dengan menggunakan program yang telah dirancan pada artikel ini dapat dilihat pada Gambar 3. Kemudian matriks penyelesaian dan gambar pohon rentang minimum dapat dilihat pada gambar 3.Jadi setelah diolah menggunakan Program diputuskan bahwa kabel panjang minimum yang diperlukan untuk menerangi 6 kamar rumah sepanjang $15000 \mathrm{~cm}$, atau 15 meter.

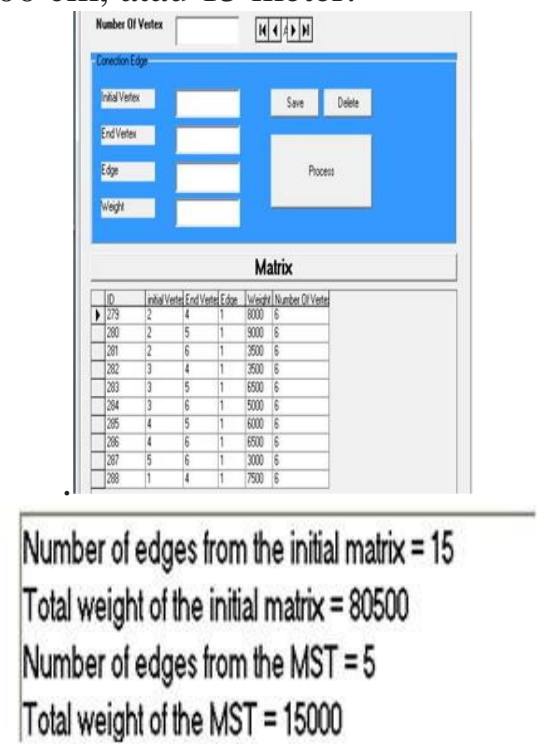

Gambar 3. matriks penyelesaian dan gambar pohon rentang minimum 


\section{MATEMATICS PAEDAGOGIC}

Vol. V No. 2, Maret 2021, hlm. 145 - 150

DOI: https://doi.org/10.36294/jmp.vxix.xxx

Available online www.jurnal.una.ac.id/indeks/jmp

\section{SIMPULAN}

Program penentuan pohon rentang minimum dengan algoritma Kruskal menggunakan aplikasi Visual Basic 6.0 terdiri dari 4 buah Form yaitu form menu yang berisi daftar form daftar yang ada pada program, form uraian sebagai form yang menggambarkan judul program, form input data sebagai data input pengguna pada simpul bilangan dan keterhubungan antara dua titik dan bobot sisinya dan terakhir membentuk matriks sebagai program menampilkan keluaran dalam bentuk

\section{DAFTAR RUJUKAN}

Abdusakir. 2009. Teori Graf Topik Dasar Untuk Tugas Akhir/Skripsi. Malang: UIN Malang.

Afrianto, Irawan., Jamilah, Euis Widiani. Oktober 2012, Penyelesaian Masalah Minimum Spanning Tree (MST) Menggunakan Ant Colony System (ACS), Jurnal Ilmiah Komputer dan Informatika, vol.1(2):35-40.

http://komputa.if.unikom.ac.id/j urnal/penyelesaian-masalahminimum.p. (diakses 24 Agustus 2016.

Bentley, Whitten. 2009. System Analysis And Design Method. Avenue of the Americas, NewYork.

Chartrand, Gary \& Lesniak, Linda. 1986. Graphs \& Digraphs. $2^{\text {rd }}$ matriks dan nilai bobot pohon rentang minimum dari grafik. Program ini dirancang untuk menentukan pohon rentang minimum menurut algoritma Kruskal langkah-langkah pengurutan berdasarkan bobot dari yang kecil sampai yang besar. Kemudian dibuat cangkok kosong yang menutupi semua titik pada grafik, kemudian dipilih dengan bobot terkecil, tetapi tidak membentuk lingkaran dengan sisi yang telah dipilih sebelumnya.

edition, California : Greg Hubit Bookworks.

Harary, Frank. 1969. Graph Theory (Copyright). Philipina : AddisonWesley Publishing Company.

Khanam, A. \& Mathew, M. 2012. Minimum Spanning Tree of Undirected Graphs.

International Journal of Engineering Research \& Technology (IJERT), 1(10): 1-Tersedia di http://www.ijert.org [diakses 221-2013].

Pan, Da-Zhi, et al. "The application of union-find sets in kruskal algorithm." Artificial Intelligence and Computational Intelligence, 2009. AICI'09. International Conference on. Vol. 2. IEEE, 2009 